\title{
НАТАЛИЯ НЯГОЛОВА
}

(iD) https://orcid.org/0000-0001-5535-7224

Великотырновский университет

им. Святых Кирилла и Мефодия

Кафедра русистики

5003 Велико-Тырново

ул. Теодосий Тырновский 2

МГУ им. М.В. Ломоносова

Кафедра славянской филологии

119992 Москва

Ленинские горы

I корпус гуманитарных факультетов

nniagolova@abv.bg

\section{НОВАЯ ТЕЛЕСНОСТЬ “ОТТЕПЕЛИ» В ПОВЕСТИ В. АКСЁНОВА КОЛЛЕГИ И ЕЕ ЭКРАНИЗАЦИИ}

\author{
THE NEW BODY OF THE “THAW" \\ IN VASILY AKSYONOV'S NOVELLA COLLEAGUES \\ AND ITS FILM ADAPTATION
}

В статье рассматривается концепция телесности в повести Василия Аксенова Коллеги и одноименном фильме 1962 года режиссера Алексея Сахарова. Исследуются новые моменты презентации тела в эпоху «оттепели» - медикализация, эротизация, электронизация. Дефинируются три модели телесности в произведении и прослеживаются их трансформации в экранизации повести.

Ключевые слова: поэтика, телесность, «оттепель», сексуальность, медицинский дискурс.

The article focuses on the concept of body representation in Vasily Aksyonov's short novel Colleagues and in Aleksei Sakharov's 1962 film of the same title. The new ways in which the body began to be represented during the "Thaw" are reported - its medicalization, eroticization, and electronization. The paper describes the three models of corporality from the novella and traces their transformations in the screen adaptation.

Keywords: poetics, body, “Thaw”, sexuality, medical discourse.

Репрезентация человеческого тела в повести В. Аксенова Коллеги и одноименном фильме А. Сахарова демонстрирует параметры оппозиции 
«физическое - духовное» времен хрущевской «оттепели». Телесный код является важнейшей координатой художественной структуры этих произведений. В нем динамическим образом сочетаются семы «здоровье»- «болезнь», «гармоничность» - «ущербность», «норма» - «патология». По мнению Е. И. Викулиной, телесный дискурс «оттепели» отличается медикализацией, эротизацией, электронизацией ${ }^{1}$. Выносливости, гигиене, репродуктивности тела в советском искусстве сталинской эпохи «оттепель» противопоставляет естественность и одухотворенность телесности.

Повесть В. Аксенова Коллеги (1959) выявляет целый ряд стилевых особенностей «оттепели» - двойнственность финала, недосказанность, неразрешимость конфликтов, лиризация повседневности. Несмотря на новизну эстетической парадигмы, искусство «оттепели» сохраняет клише преодоления и жертвенности «большого стиля» ${ }^{2}$. Инициационный сюжет повести, связанный с нравственным и профессиональным «крещением» трех молодых врачей, восходит к глобальному инициационному сюжету соцреализма, по правилам которого, как пишет К. Кларк, «молодой человек подвергается ряду испытаний и в случае успешного их преодоления посвящается и становится полноценным членом родового сообщества» ${ }^{3}$.

В повести телесный дискурс развертывается в двух планах - в медицинско-профессиональном, поскольку главные персонажи - врачи, и на уровне художественного метаязыка - «того неизбежно искусственного языка» по Р. Барту, на котором строится литературное изображение.

Однако клинические случаи в произведении Аксенова представлены минимально. Подробности врачебных будней являются только средством для выявления нравственных дилемм. Их должны решать молодые люди, сталкиваясь с косностью системы и общественными «вредителями»: мещанами, алкоголиками, преступным миром.

Тело в повести - это не столько объект инвазии и терапии, сколько субъективный, приватный феномен человеческого существования. И в этом смысле его семиотические проекции - многогранные, сложные, показанные сквозь новую, «оттепельную», оптику изображения героя.

\footnotetext{
${ }^{1}$ Е. И. Викулина, Конструирование новой телесности: медикализация и забота о себе в годы «оттепели», «Социс» 2010, № 9, с. 118-119.

${ }^{2}$ Е. Ярская-Смирнова, П. Романов, Герои и тунеядцы: иконография инвалидности в советском визуальном дискурсе, [в:] Визуальная антропология: режимы видимости при соииатизме, под ред. Е. Ярской-Смирновой, П. Романова, Москва: Вариант, ЦСПГИ 2009, с. 313.

${ }^{3}$ К. Кларк, Анализ условного советского романа. Основополагающая фабула, [в:] Советский роман: история как ритуал, Екатеринбург: Изд-во Уральского гос. ун-та 2002, [электронный ресурс] https://www.media.ls.urfu.ru/493/1258/2725/2589/1218/ [22.03.2020].

${ }^{4}$ Р. Барт, Литература и метаязык, [в:] Избранные работы: Семиотика. Поэтика, Москва: Прогресс 1994, с. 131.
} 
Телесность как визуально-поведенческая характеристика персонажа представлена в повести тремя моделями:

Модель инвалида. Она воплощена в образе ветерана войны, председателя поселкового совета Егорова. Данный образ вписывается в типологический ряд персонажей советского искусства послевоенных лет, где вернувшийся с фронта герой-калека - общее место 5 . Этот персонаж в контексте советской идеологии связывается с «второстепенными фигурами авторитетных и идеологически сознательных помощников, выполняющих роль отцов-наставников, указывающих правильный путь и воспитывающих молодого героя» ${ }^{6}$ В соцреализме инвалидность эксплицирует «патриотизм, военную героику, представления о “настоящих людях”, отважных супер-калеках, преодолевающих все преграды» ${ }^{7}$. При знакомстве с молодыми людьми Егоров, этот «кругленький, толстенький инвалид с костылем в правой руке», произносит, будучи навеселе, запутанную фразу: «Куда клонится индекс, точнее индифферент ваших посягательств?» ${ }^{8}$. Несмотря на его физическую ущербность, многократные упоминания «круглости» Егорова связываются с его внутренней гармоничностью и уверенностью. Он воспринимает свой недуг как парадоксальное условие для налаженной личной жизни: «Я сейчас подумал, доктор, что будь у меня обе ноги целы, я вряд ли имел бы сейчас тихую семейную жизнь» (с. 105). Егоров продолжает ряд экранных героев-инвалидов в советском искусстве, чьи физические дефекты «представляют метафору контраста (слабость тела - сила духа)»: Павел Корчагин, Алексей Мересьев, Юрий Ершов из Неоконченной повести. «Оттепель» сохраняет таким образом клише «большого стиля», интерпретируя инвалидность как «олицетворение силы народа», а девиантный герой становится «alter-ego главного героя, ведущий его к просветлению» ${ }^{9}$.

Двойником Егорова в фильме является доктор Дампфер - «морской волк» карантинной службы, «волшебник в драпвелюровом пальто», опекун Леши и Владьки, который лишен телесных девиаций, но зато, так же как и Егоров, имеет особый статус посвященного героя (оборона Кронштадта, путешествия в дальные страны).

\footnotetext{
${ }^{5}$ А. Куляпин, О. Скубач, Тело как текст, или Body-art тоталитаризма, [в:] Мифология советской повседневности в литературе и культуре сталинской эпохи, Москва: Языки славянской культуры 2013, с. 93.

${ }^{6}$ Х. Гюнтер, Архетипы советской культуры, [в:] Соиреалистический канон, [электронный ресурс] https://media.ls.urfu.ru/493/1258/2726/2592/1235 [22.03.2020].

${ }^{7}$ Е. Ярская-Смирнова, П. Романов, Герои и тунеядиъь.., с. 305.

${ }^{8}$ В. Аксёнов, Коллеги, [в:] Звездный билет, Москва: Эксмо 2014, с. 21. Далее цитаты из повести В. Аксёнова даются по этому изданию с указанием страницы в скобках.

${ }^{9}$ Е. Ярская-Смирнова, П. Романов, Герои и тунеядиьь..., с. 291.
} 
Модель «здоровяка». Олицетворением грубой физической силы в фильме становится Федор Бугров - тунеядец и криминальный тип. Этими социальными характеристиками он вписывается в клише «вредителя», который в эпоху «оттепели» уже не отождествляется с иностранным шпионом или «врагом народа» с партбилетом, а приобретает «мещанско-индивидуалистический» облик ${ }^{10}$. Первая встреча Зеленина с Бугровым заставляет молодого врача почувствовать себя слабым и беззащитным:

\begin{abstract}
Теперь он понял, чем это вызвано: в упор на него, не мигая, смотрели серые страшные глаза. Они принадлежали парню атлетического сложения, который лежал поверх одеяла, скрестив на груди голые руки. Могучие эти татуированные руки с вяло перекатывающимися под кожей шарами бицепсов напоминали нажравшегося питона. Вообще казалось, что парень только потому не крушит все вокруг себя, что в эту минуту он дьявольски сыт (с. 94).
\end{abstract}

Несмотря на свою атлетическую форму, Бугров напоминает скорее машину, злой механизм - его легкие дышут «как мехи», а пульс сравнивается с работой мотора. Портрет Бугрова и его биография (у него бабка в Гатчине - «известная травница, богатющая, ведьма»; он неожиданно исчезает и зловеще-мистически появляется) вписывают персонажа в мифологическую парадигму нечисти. После нападения на Зеленина Бугров прячется в севастиановской баньке, чей топос в его фольклорно-мифологическом прочтении связан с нечистой силой. К «вредителям» Бугрова позволяют отнести не только особенности его телесности. Довольно странным на фоне остальных героев кажется костюм героя. Хромовые сапоги «в гармошку», кепочка-«лондонка», синий костюм отличного бостона, голубая «бобочка» с молнией - всё это элементы несоветского дресскода. В этом костюме Н. Лебина видит смесь «криминального шика» 1940-х годов и элементов «сталинского гламура» ${ }^{11}$. В фильме А. Сахарова Бугров одет проще, семиотика его костюма репрезентирует мифологический подтекст образа: самым представительным элементом его одежды является меховая шуба, которая демонстрирует состоятельность героя и его брутальное, животное начало.

Аналогичный художественный инструментарий используется при создании портрета «амбарного вредителя», заведующего складом Ярчука. В его описании присутствуют сравнения с материальным миром («пасхальное яичко», «пружины»), а также анималистический код («жук», «собака», «клещ»).

${ }^{10}$ В. Семерчук, Смена вех на исходе оттепели, [в:] Проза.ру [электронный ресурс] https://www.proza.ru/2011/11/09/878 [22.03.2020].

${ }^{11}$ Н. Лебина, Мужчина и женщина: тело, мода, культура. СССР - Оттепель, Москва: Новое литературное обозрение 2014, с. 120. 
Модель спортсмена. К этой модели относится образ трех молодых «коллег». Он строится на принципах эстетико-идеологической программы «оттепели»: реабилитация заботы о собственном теле, медикализация телесности и занятия спортом, которые теряют брутальность сталинских времен, приобретая элементы мужественной интеллигентности и романтики. Вслед за медициной спорт для героев становится самой репрезентативной сферой. Именно на период «оттепели» приходится пик развития советского спорта, а спортивным соревнованиям отводится особая роль в противостоянии коммунистического общества капиталистическому Западу ${ }^{12}$. Владька Карпов и Алексей Максимов представляют себя, в первую очередь, через спорт: «Да, конечно, я спортсмен. Разве не видно? Всеми видами спорта. Больше всего люблю бильярд» (с. 9); «В школе я играл в футбол, а в институте - в волейбол. Я и сейчас играю в волейбол и всегда буду в него играть» (с. 10). На волейбольной площадке после блестящего удара Саша впервые видит Инну, которая «водит сбоку гоночный велосипед». Парни плавают и катаются на лыжах. Саша не изменяет утренней зарядке даже в трудные дни распределения, а его спортивный костюм оттеняет неодобряемый жителями поселка вид доктора, который гоняется за мячом в одном «исподнем». Тело самого красивого из них - Владьки Карпова - как бы живет собственной жизнью, ошеломляя окружающих: «извивающееся тело», «бронзовые плечи», «мускулы играли под глянцевитой кожей, как рыбы». Однако именно этому «мулатоподобному южанину» меньше всех везет в любви. В фильме образ Карпова сильно изменен. Внешне он самый незаметный среди троих друзей, веселый, немного смешной. На фоне красавцев Зеленина и Максимова (в исполнении В. Ливанова и В. Ланового) герой О. Анофриева несколько похож на Санчо Панса, тем более, что Саша неоднократно назван в тексте «рыцарем» и даже «рыцарем печального образа». По-видимому, Сахаров старается редуцировать идеальность «коллег». Эмоциональные пристрастия Владьки в повести выражаются в ряде «встреч», а единственная любимая женщина Вера его отвергает.

Молодые врачи не только спортсмены, но и танцоры. Н. Лебина отмечает, что «танцевальные пристрастия у Аксенова выступают маркером социальной позиции личности» и связь каждого героя с определенным танцем демонстрирует «в условиях цензуры отношение власти к разным видам танцев» ${ }^{13}$. Так, Саша предпочитает вальс, Владька - фокстрот, а мрачный

12 Л. Л. Агаджанян, «Отттепель» в истории отечественной культуры: конъюнктурное u непреходящее, «Вестник Московского государственного университета культуры и искусств» 2015, № 4 (66), c. 88-89.

${ }^{13}$ Н. Лебина, Мужчина и женщина..., с. 22. 
Максимов «знает о существовании буги-вуги». Правда, всё это происходит в фильме, а в повести первый танец Зеленин и Инна исполняют под звуки танго Кампарасита. Режиссер отступает от литературного источника, чтобы подчеркнуть интеллигентность Саши и противопоставить его Бугрову, предлагающему Даше «сбацать танхо».

В тесной связи с танцевальными пристрастиями развивается и любовная жизнь молодых врачей. Легкомысленный фокстрот проецируется на мимолетные отношения очаровательного Карпова с женщинами. Его «подвиги» сообщаются только как история героя, но остаются «за кадром». Сюжет повести пронизывают две бурные любовные линии - романтичная история Зеленина и Инны и тайная связь Максимова и Веры. Возвышенные чувства Саши сочетаются со свободными сексуальными отношениями. Исследователи отмечают, что в кинематографе «оттепели» добрачные связи нередко «выступают как норма частной жизни советской интеллигенции» 14 . Страстная любовь нигилиста Максимова к Вере ослепляет его, лишает уверенности и втягивает в заколдованный круг встреч и расставаний. В эпизодах любовных свиданий присутствие и эмоции Веры даны через описание ее лица («странный, слепящий блеск в глазах Веры», «ставшие озорными глаза», «большие, дрожащие глаза», «печальное и изучающее лицо», «спокойная, ласковая улыбка») и через изменения голоса Алексея - неестественный, насмешливый, мрачный голос.

По мнению Т. Дашковой, одна из основных особенностей «оттепельного» кино - наличие эротической составляющей ${ }^{15}$. Эту составляющую легко увидеть в повести Аксенова. Она продолжает традицию Э. М. Ремарка и Э. Хемингуэя - страстный жест на фоне молчания или словесной скупости $^{16}$. Однако в фильме А. Сахарова линия любви Алексея Максимова к замужней однокурснице Вере отстутствует, отношения Зеленина и Инны лишены эротизма, а самая страстная сцена - их вальс. Остальное общение подается в духе женско-мужских отношений «товарищества» и «дружбы», хорошо известных по текстам «большого стиля». В фильме неоспорима сексуальная внешность Инны (Н. Шацкая). Она никогда не появляется

${ }^{14}$ Н. Лебина, Мужчина иженщина..., с. 39. Исследовательница приводит в качестве примера отношения между Гусевым и Лёлей в фильме М. Ромма Девять дней одного года (1962).

${ }^{15}$ Т. Дашкова, Границы приватного в советских кинофильмах до и после 1956 года: проблематизация переходного периода, [в:] Телесность - Идеология - Кинематограб: Визуальный канон и советская повседневность, Москва: Новое литературное обозрение 2013, c. $146-147$.

${ }^{16}$ Некоторые аспекты данного соотношения комментируются в статье: Т. В. Шумакова, Повести Василия Аксенова «Коллеги» и «Звездный билет» в контексте зарубежной литераmypы, «Вестник Челябинского государственного университета» 2001, т. 2, № 1, с. 80-88. 
в «брючках», как в повести, а только в диоровских платьях; даже в квартире доктора в Круглогорье на героине вечерний туалет.

Образами героев-любовников, Зеленина и Максимова, Аксенов отдает дань основным литературным кумирам «оттепели» - Ремарку и Хемингуэю и их героям. Ремарковское отношение к женщинам и любви проявляется в отношении Зеленина к Инне: герой стремится создать «мирок» для двоих посреди профессиональных и общественных коллизий. Если в сфере частной жизни Зеленин напоминает Роберта Локампа, то профессиональное бытие роднит его с Чеховым. Внешность Зеленина имеет сходство с внешностью Чехова (худощавый, высокий, бледный, в очках), а в фильме сходство визуализируется: в его квартире висит портрет Антона Павловича. Эта интертекстуальная параллель подчеркивает интеллигентское происхождение доктора Зеленина, актуализирует связь поколения молодых врачей с дореволюционной русской интеллигенцией ${ }^{17}$.

Алексей Максимов - герой хемингуэевского типа. Его поведенческие черты - нигилизм, невыносимость к «высоким словесам», решительность и резкость. Любовь героя к Вере - немногословная и страстная, и он, страдая, но не жалуясь, готов нести бремя привязанности к замужней женщине. Диалоги между героями отличаются хемингуэевской недосказанностью: «Каждое слово в тот день было подобно заголовку интересной книги: оно интриговало, но не раскрывало смысла» (с. 123). В духе оттепельного стремления к естественности любовь подчиняется новым правилам - «любить не из-за чего-то, а просто так»; знак равенства между браком и любовью не обязателен. Алексей убеждает себя: «Это я ее муж! Только я, и никто другой» (с. 132). Для Максимова любовь к Вере изменяет мироздание: «Скрипнула ось земли, и планета отлетела куда-то в сторону. Мир изменился, замелькал. В центре вселенной, пронизывая Млечный Путь, выросла и зашаталась гигантская тень влюбленной пары» (с. 125). Во вселенских трансформациях, спровоцированных любовью, можно рассмотреть перекличку с ощущениями Марии и Роберта Джордана у Хемингуэя: «[...] и вдруг в неожиданном, в жгучем, в последнем весь мрак разлетелся и время застыло, и только они двое существовали в неподвижном остановившемся времени, и земля под ними качнулась и поплыла» ${ }^{18}$.

Любовь к Вере Алексей переносит на ее дом; он исследует его, подобно телу любимой женщины:

Окна широкие, как в современных домах, а по фасаду разбросаны добротные излишества, над парадным возлежит гранитная наяда. Седьмой этаж мансардный, там

\footnotetext{
${ }^{17}$ Проблема преемственности и связи между поколениями - одна из основных в повести.

${ }^{18}$ Э. Хемингуэй, По ком звонит колокол, Москва: АСТ 2019, с. 223.
} 
крутые скаты крыши, какие-то мелкие башенки. Немного готики, и романский стиль, и даже барокко (с. 133).

И дальше: «Люблю ее глаза, волосы, губы, ее тело, ее слова и ее костюмы, привычки, смех, ошибки, печаль, ее дом, ее улицу, весь этот район, люблю и доброжелательно отношусь к милиционеру, который в третий раз проходит мимо» (с. 133). Архитектурная образность очень характерна для кинематографа «оттепели» как проявление слияния природы и городской среды, живого и неживого в художественной концепции шестидесятников ${ }^{19}$.

Все указанные модели телесности в фильме можно рассмотреть и как актанты инициационного сюжета. Образ инвалида Егорова относится к архетипу мудрого старика - своеобразный психопомп для «подвигов» Зеленина. Стихийная монструозность Бугрова в сочетании с его анималистическими характеристиками восходит к архетипу Змея, а образы трех коллег - варианты героя-подростка, который проходит через все этапы инициации: изоляция, мнимая смерть, воскресение.

Экранизация повести оказывается более консервативной, чем сама повесть. В фильме отстутствуют те сюжетные линии, которые вносят характерную для «оттепели» многозначность и неразрешимость конфликта. Сюжетная редукция компенсируется ярким визуальным рядом, а доминантный телесный код оживлен целой плеядой молодых актеров, превратившихся в олицетворение духа «оттепели»- Василий Ливанов, Василий Лановой, Нина Шацкая, Тамара Сёмина.

\section{References}

Agadzhanyan, Leon L. "Ottepel' v istorii otechestvennoi kultury: konyunkturnoe i neprekhodyashchee". Vestnik Moskovskogo gosudarstvennogo universiteta kultury i iskusstv. No. 4 (66), (2015): 85-89.

Aksenov, Vasilii. Kollegi. In: Zvezdnyi bilet. Moskva: Eksmo, 2014.

Barthes, Roland. Izbrannye raboty: Semiotika. Poetika. Moskva: Progress, 1994.

Dashkova, Tatyana. Telesnost - Ideologiya - Kinematograf: Vizualnyi kanon i sovetskaya povsednevnost. Moskva: Novoe literaturnoe obozrenie, 2013.

Gyunter, Hans. Arkhetipy sovetskoi kultury. https://media.ls.urfu.ru/493/1258/2726/2592/1235

Hemingway, Ernest. Po kom zvonit kolokol. Moskva: AST, 2019.

Klark, Katerina. Analiz uslovnogo sovetskogo romana. Osnovopolagayushchaya fabula. https://www.media.ls.urfu.ru/493/1258/2725/2589/1218/

Kulyapin, Aleksandr, Skubach, Olga. Mifologiya sovetskoi povsednevnosti v literature i kulture stalinskoi epokhi. Moskva: Yazyki slavyanskoi kultury, 2013.

Lebina, Natalya. Muzhchina i zhenshchina: telo, moda, kultura. SSSR - Ottepel. Moskva: Novoe literaturnoe obozrenie, 2014.

${ }^{19}$ Д. И. Михейкин, Архитектура в кино 1960-х, [в:] Эстетика «оттепели»: новое в архитектуре, искусстве, культуре, Москва: РОССПЭН 2013, с. 292. 
Mikheikin, Dmitrii I. Arkhitektura v kino 1960-kh. In: Estetika 'ottepeli': novoe v arkhitekture, iskusstve, kulture, ed. O. V. Kazakovaya. Moskva: ROSSPEN, 2013: 291-327.

Semerchuk, Vladimir. Smena vekh na iskhode ottepeli. https://www.proza.ru/2011/11/09/878

Shumakova, Tatyana V. "Povesti Vasiliya Aksenova "Kollegi" i "Zvezdnyi bilet" v kontekste zarubezhnoi literatury”. Vestnik Chelyabinskogo gosudarstvennogo universiteta. Vol. 2. No. 1 (2001): 80-88.

Vikulina, Yekaterina I. "Konstruirovanie novoi telesnosti: medikalizatsiya i zabota o sebe v gody 'ottepeli”'. Sotsis. No. 9 (2010): 113-119.

Yarskaya-Smirnova, Yelena R., Romanov, Pavel V. Geroi i tuneyadtsy: ikonografiya invalidnosti v sovetskom vizualnom diskurse. In: Vizualnaya antropologiya: rezhimy vidimosti pri sotsializme, ed. Ye. Yarskaya-Smirnova, P. Romanova. Moskva: Variant, TsSPGI, 2009: 289-331. 